1 Bender WI. ACE inhibitors for prophylaxis of migraine headaches. Headache 1995;35:470-1.

2 International Headache Society Committee on Clinical Trials in Migraine. Guidelines for controlled trials of drugs in migraine. Cephalalgia 1991;11/1:1-12.

3 Headache Classification Committee of the International Headache Society. Classification and diagnostic criteria for headache disorders, cranial neuralgias and facial pain. Cephalalgia 1988;8(suppl 7):1-96.

4 Ware JE, Gandek B, IQOLA project group. The SF-36 health survey: development and use in mental health research and the IQOLA project. Int J Mental Health 1994;23:49-73.

5 Lachin JM. Introduction to sample size determination and power analysis in clinical trials. Control Clin Trials 1981;2:93-113.

6 Tfelt-Hansen P, Shanks RG. Beta-adrenoceptor blocking drugs. In: Olesen J, Tfelt-Hansen P, Welch M, eds. The headaches. New York: Raven Press, 1993:363-72.

7 Holroyd KA, Penzien DB, Cordingley GE. Propranolol in the management of recurrent migraine: a meta-analytic review. Headache 1991;31:33-40.

8 Altman DG. Practical statistics for medical research. London: Chapman and Hall, 1991:447-8.
9 Goa KL, Balfour JA, Zuanetti G. Lisinopril. A review of its pharmacology and clinical efficacy in the early management of acute myocardial infarc tion. Drugs 1996;52:564-88.

10 Skidgel RA, Erdos EG. The broad substrate specificity of human angiotensin converting enzyme. Clin Exp Hypertens A 1987;9:243-59.

11 Paterna S, Di Pasquale P, D'Angelo A, Seidita G, Tuttolomondo A, Cardinale A, et al. Angiotensin-converting enzyme gene deletion polymorphism determines an increase in frequency of migraine attacks in patients suffering from migraine without aura. Eur Neurol 2000;43;133-6.

12 Huckell VF, Belanger LG, Kazimirski M, Subramanian T, Cox AJ. Lisinopril in the treatment of hypertension: a Canadian postmarketing surveillance study. Clin Ther 1993;15:407-22.

13 Fogari R, Zoppi A, Corradi L, Mugellini A, Poletti L, Lusardi P. Sexual function in hypertensive males treated with lisinopril or atenolol: a crossover study. Am J Hypertens 1998;11:1244-7.

14 Tomlinson AJ, Campbell J, Walker JJ, Morgan C. Malignant primary hypertension in pregnancy treated with lisinopril. Ann Pharmacother $2000 ; 34: 180-2$.

(Accepted 9 October 2000)

\title{
Existence and quality of written antenatal screening policies in the United Kingdom: postal survey
}

\author{
Beverley Lane, Kirsty Challen, Hilary J Harris, Rodney Harris
}

Genetic Enquiry Centre, St Mary's

Hospital,

Manchester

M13 0JH

Beverley Lane

research nurse

Kirsty Challen

research assistant

Hilary J Harris

research associate

Rodney Harris

emeritus professor

(medical genetics)

Correspondence to:

K Challen

kirstychallen@

hotmail.com

BMJ 2001;322:22-3

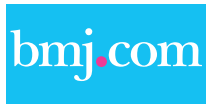

Copies of the questionnaires are available on the BMJ's website
The assessment of antenatal care of women at increased risk of having a baby with Down's syndrome, neural tube defect, thalassaemia, and cystic fibrosis that was undertaken by the national confidential inquiry into counselling by non-geneticists revealed several problems, including poor record keeping. ${ }^{1}$ These problems were reported to the Department of Health in five specific papers and four summary, peer reviewed papers and on the internet. ${ }^{2}$ The Royal College of Obstetricians and Gynaecologists then issued guidelines recommending that antenatal units have written policies for screening for Down's syndrome and for neural tube defect and that haemoglobinopathy screening be offered to all patients whose ethnic origin makes them susceptible. ${ }^{3}$ There is less consensus on screening for cystic fibrosis (UK National Screening Committee, joint meeting of the antenatal and child health screening subgroups, cystic fibrosis workshop, London, 2 June 1999). We assessed the response among antenatal staff to the outcomes of the national confidential inquiry.

\section{Methods and results}

In 1999 directors of obstetrics and midwifery throughout the United Kingdom were asked to complete an anonymous questionnaire concerning their awareness of the national confidential inquiry and its effects on practice. (Copies of the questionnaires are available on the $B M$ /s website.) Midwives were also asked to submit their unit's written policies, which we assessed using the royal college's criteria (table).

A total of 242 obstetricians were sent questionnaires, $181(75 \%)$ of whom responded. Of these, 29 $(16 \%)$ were aware of the inquiry (four having supplied information to it), 13 (7\%) were aware of the specific recommendations for Down's syndrome, 7 (4\%) those for neural tube defects, and $6(3 \%)$ those for cystic fibrosis. Four obstetricians stated that they had implemented recommendations, and one was auditing their effect on practice. Of the 273 midwives who were sent questionnaires, 160 (59\%) responded; 33 (21\%) were aware of the inquiry, $27(18 \%)$ were familiar with the recommendations for Down's syndrome, 13 (9\%) those for neural tube defects, and $9(6 \%)$ those for cystic fibrosis. The figures for obstetricians and those for midwives are not evidently related.

Thirty nine units (24\%) lacked local and regional policies for Down's syndrome, 55 (34\%) for neural tube defect, 104 (65\%) for haemoglobinopathy, and 125 (78\%) for cystic fibrosis; 55 units updated their policies annually, 36 "[when] required", one every five years,

Adherence of midwifery units' written policies to Royal College of Obstetricians and Gynaecologists' guidelines on screening*

\begin{tabular}{lcl} 
Royal College guidelines criterion & $\begin{array}{c}\text { No (\%) of policies } \\
\text { fulfilling criterion }\end{array}$ & Comments \\
\hline $\begin{array}{l}\text { Clear statement of which test is available } \\
\begin{array}{l}\text { Clear statement of which patients are routinely } \\
\text { to be offered test }\end{array}\end{array}$ & $61(94)$ & Missing in one policy on Down's syndrome and three on haemoglobinopathy \\
\hline $\begin{array}{l}\text { Personnel responsible for offering screening or } \\
\text { counselling are specified }\end{array}$ & $13(20)$ & $\begin{array}{l}11 \text { offer testing for Down's syndrome to all, } 9 \text { to women aged } 30-38 ; \text { three offer } \\
\text { haemoglobinopathy testing to unspecified ethnic groups, one universally; both } \\
\text { policies covering cystic fibrosis state family history as basis for screening }\end{array}$ \\
\hline $\begin{array}{l}\text { Clear statement of cut-off values for normality } \\
\text { Clear guidelines on referral for abnormal screen }\end{array}$ & $22(34)$ & $\begin{array}{l}\text { In 4/14 of policies for both Down's syndrome and NTD, 5/20 for Down's syndrome, } \\
5 / 11 \text { for NTD, and 8/18 for haemoglobinopathy }\end{array}$ \\
\hline
\end{tabular}

*Of 65 written policies, 20 covered Down's syndrome, 11 neural tube defect (NTD), 14 both Down's syndrome and NTD, 2 cystic fibrosis, and 18

haemoglobinopathy. 
and one every three months. Neither awareness of the inquiry nor whether a coordinator was responsible for screening had an effect on the updating of policies. In 108 units $(90 \%)$ policies were said to be agreed by everyone implementing them. One unit reported that community midwives were excluded from agreement of policy, another that medical staff constructed policies without consulting midwives. Written policies were received from 65 midwifery units; the adherence of these policies to the royal college guidelines is shown in the table.

A key person responsible for coordinating screening was reported in 106 units (68\%). This correlated with the existence of a local policy for Down's syndrome $(\mathrm{P}=0.045)$ but not for neural tube defect or haemoglobinopathy. Of these people 42 were midwifery managers, 23 specialist coordinators (including one genetic counsellor), and 18 consultants.

Where written policies existed they varied widely in adherence to the guidelines, and only one covered all five points. There was no evidence that obstetricians' and midwives' awareness of the inquiry (the evidence base for many policies) was consistent within units. Community midwives were sometimes excluded from policymaking, even though they were relied on for identification and initial counselling of women. One policy "agreed by all" had criteria for screening and referral that differed for each named consultant

\section{Comment}

We found that antenatal units were generally unaware of the royal college's recommendations on screening. National guidelines and local written policies should be adopted to promote informed choice and equity of service. ${ }^{1}$ Coordinated antenatal genetic screening will be even more important with the mapping of the human genome. Units without an identified person responsible for antenatal screening face the risk of being overwhelmed by advances in the field, and national audits will be compromised if no single person can be approached for reliable information.

Competing interests: None declared.

Funding: Department of Health's confidential inquiry into genetic counselling by non-geneticists.

Contributors: BL conceived the study and distributed questionnaires. BL and KC collated and analysed data. HJH contributed to interpretation and analysis of data. The paper was written jointly by all authors. RH is the guarantor for the study.

1 Harris R, Lane B, Harris H, Williamson P, Dodge J, Modell B, et al. National confidential enquiry into counselling for genetic disorders by non-geneticists: general recommendations and specific standards for improving care. Br J Obstet Gynaecol 1999;106:658-63.

2 Confidential Enquiry into Genetic Counselling by Non-Geneticists. www.medicine.man.ac.uk/geneticenquiry/counsell.htm (accessed 9 Oct 2000).

3 Royal College of Obstetricians and Gynaecologists Clinical Audit Unit. Effective procedures in maternity care suitable for audit. London: RCOG, 1997

(Accepted 1 August 2000)

\section{Drug points}

\section{Tachycardia associated with moxifloxacin}

Martin Siepmann, Wilhelm Kirch, Institute of Clinical Pharmacology, Medical Faculty, Technical University, 01307 Dresden, Germany

The fluoroqinolone grepafloxacin has been associated with tachycardia in animals and humans. ${ }^{12}$ It was eventually withdrawn from use owing to prolongation of the QT interval. Another fluoroquinolone, moxifloxacin (Avalox, Bayer Vital), was introduced in Germany in September 1999 and two months later in the United States. The chemical structure of moxifloxacin is similar to that of grepafloxacin, and both drugs have a broad spectrum of activity against bacteria, including Gram positive bacteria. Up to March 2000 about one million patients have been treated with moxifloxacin, and half of them have been evaluated for adverse events (Bayer Vital, personal communication). We describe the first case of tachycardia associated with moxifloxacin.

A 49 year old non-febrile man was prescribed moxifloxacin for sinusitis and bronchitis. About 45 minutes after taking the daily dose of $400 \mathrm{mg}$ moxifloxacin he developed tachycardia ( 120 beats per minute). About 60 minutes before taking the moxifloxacin he had taken $500 \mathrm{mg}$ aspirin for a headache. He described the tachycardia as "thumping" palpitations, which he had never before experienced. The symptoms lasted for 45 minutes. Tachycardia did not recur when moxifloxacin was restarted. The patient has no history of cardiovascular disease and regularly exercised on cycle and rowing machines. The day before the tachycardia an electrocardiogram was recorded that gave normal results (sinus rhythm 75, no abnormal changes).

We informed the German Federal Institute for Drugs and Medical Devices and the Drug Commission of the
German Medical Profession. They cited 19 other reported cases of tachycardia in association with moxifloxacin.

The underlying mechanism may be vasodilatation either directly or indirectly owing to release of histamine with reflex tachycardia. These effects have been described for fluoroquinolones such as flosequinan. ${ }^{34}$ Tachycardia could also be due to prolongation of the QT interval. Prolongation (QT interval > 450 milliseconds) has been documented in 38 patients treated with $400 \mathrm{mg}$ moxifloxacin daily. ${ }^{5}$

\section{Competing interests: None declared.}

1 Stahlmann R, Schwabe R. Safety profile of grepafloxacin compared with other fluorochinolones. J Antimicrob Chemother 1997;40(suppl A):83-92.

2 Lode H, Vogel F, Elies W. Grepafloxacin: a review of its safety profile based on clinical trials and post marketing surveillance. Clin Ther 1999;21:61-74

3 Takayama S, Hirohashi M, Kato M, Shimada H. Toxicity of quinolone antimicrobial agents. J Toxicol Environ Health 1995;45:1-45.

4 Janssen MC, Smits P, Reyenga J, Thien T. Acute effects of flosequinan (BTS 49465) in untreated moderate to severe hypertension. J Hum Hypertens 1995:9:363-8.

5 Balfour JA, Lamb HM. Moxifloxacin. A review of its clinical potential in the management of community-acquired respiratory tract infections. Drugs 2000;59:115-39.

\section{Endpiece}

\section{For a sundial}

Loss and Possession, death and life are one, There falls no shadow where there shines no sun.

Hilaire Belloc (1870-1953), For a sundial

Submitted by Fred Charatan,

retired geriatric physician, Florida 